\title{
EXTRAMARITAL AFFAIRS, MARITAL SATISFACTION, AND DIVORCE: EVIDENCE FROM HONG KONG
}

\author{
C. SIMON FAN and HON-KWONG LUI*
}

\begin{abstract}
This article provides the first empirical study on how the perceived changes of marital satisfaction affect marital stability using a unique data set obtained in Hong Kong. It is found that the change of marital satisfaction due to extramarital affairs clearly increases the probability of divorce, but it is not the only determinant of marital instability. In particular, the presence of dependent children in a family and good marital quality before the discovery of extramarital affairs would lower the probability of divorce. Moreover, this article generates several interesting policy implications. (JEL D1, J1)
\end{abstract}

\section{INTRODUCTION}

Once the rock on which society was founded, marriage has been becoming increasingly unstable in many developed countries for the past few decades. For example, a high proportion of all first marriages in the United States are likely to end in divorce, whereas remarriage with new partners are not less prone to dissolution (e.g., Lillard and Waite, 1990). In the United States, the divorce rate had risen steadily from 2.5 per 1000 population in 1966 to a peak of 5.3 in both 1979 and 1981 (Clarke, 1995a). On the other hand, the marriage rate reached a historic high of 16.4 per 1000 population in 1946 and started declining (Clarke, 1995b). Both rates continue to decline and for the 12-month ending with September 2003 , the marriage rate and divorce rate were 7.6 and 3.8, respectively (Sutton and Munson, 2004). Indeed, divorce is one of the salient features of modern life that has important implications for social and public policy. This article extends the existing literature by examining the divorce decisions of the individuals who experienced marital infidelity.

Economists and other social scientists suggest a variety of socioeconomic factors that

\footnotetext{
*The authors thank Robert Michaels and three anonymous referees for useful comments and suggestions that significantly improved the quality of the article.

Fan: Associate Professor, Department of Economics, Lingnan University, Tuen Mun, Hong Kong. Phone 852-2616-7206, Fax 852-2891-7940, E-mail fansimon@ln.edu.hk

Lui: Associate Professor, Department of Marketing \& International Business, Lingnan University, Tuen Mun, Hong Kong. Phone 852-2616-8233, Fax 852-2467-3049, E-mail hklui@ln.edu.hk
}

determine marital disruption. For example, these variables include no-fault divorce laws (Allen, 1998), cohabitation (Walters and Ressler, 1999), government benefits (Moffitt, 1988; Ellwood and Bane, 1985; Hoffman and Duncan, 1995), age at first marriage (Becker et al., 1977), religion (Berggren, 1997), transfer of property rights of sex (Allen and Brinig, 1998), high sex ratio (Trent and South, 1989), marital and premarital births (Morgan and Rindfuss, 1988), economic independence (South, 1985; Hiedemann et al., 1998), and women's economic status (Aghajanian, 1986; Hiedemann et al., 1998).

Among others, the existing literature that is most related to this study includes Weiss and Willis (1997) and Boheim and Ermisch (2001). They extend Becker et al. (1977) and investigate how marital dissolution may result from the deviation between expected and ex post realization of uncertain events. In particular, they find that an unexpected increase in husband's earning capacity reduces the divorce hazard, whereas an unexpected increase in wife's earning capacity raises the divorce hazard.

Weiss and Willis (1997) also show that couples sort into marriage according to the characteristics, such as similar religion, ethnicity, and education, to enhance their marriage quality and stability. In modern society, marital satisfaction stems mainly from a couple's consumption in leisure activities. ${ }^{1}$ Moreover,

1. For example, Posner (1992, p. 435) describes the modern norm of marriage as "companionate marriage" with the following characteristics: "In which the husband and wife are best friends, social and emotional intimates, 
in his Nobel Prize address, Fogel (1999) has a lengthy discussion on the increasing importance of the consumption of leisure in people's economic lives.

However, largely due to lack of suitable data sets, the existing economic literature hasn't examined explicitly the quantitative relationship between marital satisfaction and divorce. It should be noted that social scientists have conducted studies in this area. For example, Nock and Brinig (2002), employ Cox proportional hazards regression to predict marital disruption based on data obtained from the National Survey of Families and Households administered in the United States.

Using a unique data set from Hong Kong, the authors try to complement the existing literature by studying how the change of marital satisfaction may affect divorce decisions. In this article the change of marital satisfaction is caused by extramarital affairs. For social, cultural and psychological reasons, extramarital affairs may have different impacts on marital satisfaction and mental well-being for different couples (e.g., Scott et al., 1993; Lee and $\mathrm{Lu}, 1997$ ).

Research conducted by sociologists show that fidelity is a very important contributor to a good marriage. In many Western countries, adultery has long been a good ground for divorce and absolute divorce could be granted. In Hong Kong, adultery and unreasonable behavior are considered sufficient grounds for divorce. In fact, getting a divorce decree in Hong Kong is not difficult. A couple could apply for a divorce by showing proof of separation, not necessarily documented by court decree, for a continuous period of at least one year (if both parties consent to the divorce) or two years (if the divorce is contested).

In traditional China, polygamy was legal. At least partly due to arranged marriage, a rich man often had more than one wife (e.g., Cheung, 1972). So a more traditional Chinese woman generally has more tolerance of her husband being involved in extramarital affairs. However, in modern times, children are no longer regarded as parents' assets, and arranged marriage has been declining sharply in Chinese societies (e.g., Xu and Whyte, 1990).

close companions." This description clearly indicates that the nonpecuniary aspects of marriage life are of utmost importance to couples.
In Hong Kong, the most Westernized Chinese society, arranged marriage should be rare and couples were highly likely to be marrying for love. Because love is a more important determining factor in one's marriage decision, people become much less tolerant of their spouses' infidelity (e.g., Liao and Heaton, 1992).

Hence it is not surprising that the divorce rate in Hong Kong showed steady increase in the past few decades. The official statistics of Hong Kong show that the number of divorce decrees granted in 2001 was 13,425, as compared with 2060 in 1981 (Census and Statistics Department, 2002). During the same period, the number of registered marriages dropped from 50,756 in 1981 to 32,825 in 2001 . These numbers explain why social and economic problems arising from marital disruption have attracted more public discussions in Hong Kong.

Caritas Family Service, a social welfare agency with financial support from the Hong Kong government, collected the data set used herein. In recent years, a large number of families in Hong Kong have been affected by extramarital affairs, especially with the increasing economic integration and social interactions between Hong Kong and mainland China. In response to this social problem, Caritas Family Service provides special counseling services to families affected by extramarital affairs. A by-product of this counseling service is the data set that the authors use, which documents detailed information of affected couples. In particular, it provides the information about an individual's assessment of marital satisfaction before and after her or his spousal partner's involvement in extramarital affairs was revealed.

Following Weiss and Willis $(1985,1997)$, the authors first set up a simple model in which marital satisfaction enters into a couple's utility function. Then in a framework of rational choice, an individual will choose to divorce if and only if one's expected utility from one's future alternatives after divorce is greater than one's utility from remaining married. An individual's future alternatives include one's perspectives of remarriage. Moreover, the utility from the current marriage depends on the damage to the quality of marriage due to the spouse's involvement in extramarital affairs. 
Then the authors test several hypotheses based on the model and the existing theory. In particular, the regression analysis indicates that although the change of marital satisfaction due to extramarital affairs clearly increases the probability of divorce, it is not the only determinant of marital instability. For example, the number of dependent children and the level of marital satisfaction before the revelation of extramarital affairs also has statistically significant impact on divorce decisions.

In what follows, section II presents a simple model that guides the empirical analysis; section III describes the data; section IV presents the empirical estimations; section V discusses the policy implications, and section VI concludes this paper.

\section{DETERMINANTS OF DIVORCE: A LOGIT MODEL}

In the data set used in this article, the participants of extramarital affairs are mostly men. So, for simplicity, throughout this section the authors assume that only husbands are involved in extramarital affairs. However, similar analysis applies equally to cases in which wives are involved in extramarital affairs.

When a wife discovers that her husband is involved in extramarital affair, she may feel betrayed, and hence her satisfaction derived from her marriage may be reduced. So divorce will occur when the utility from the current marriage is less than the expected utility of future alternatives, such as remarriage. A married individual obtains utility from both material and emotional factors, which may include her consumption, the quantity and quality of her children, and the quality of her marriage match (e.g., Weiss and Willis, 1985). Given the quality of her marriage match, the household bargaining models (e.g., Lundberg and Pollak, 1993) show that an individual's utility increases with her spouse's income as well as her own income. Thus if an individual continues with her current marriage, her indirect utility function can be expressed as

$$
u\left(I_{w}, I_{h}\right)+\theta(X)
$$

where $I_{w}$ and $I_{h}$ denote her own income and her spouse's income, respectively; the indirect utility function, $u()$, is strictly increasing with respect to its variables. $\boldsymbol{X}$ denotes some personal characteristics of herself and her spouse. The function $\theta()$ is a function of $\boldsymbol{X}$, which denotes the quality of her marriage match.

If an individual chooses to divorce, she will either remarry or remain single. In a (re)marriage market, assortative mating implies that people tend to end up with marriage partners of similar attractiveness (e.g., Becker, 1973). An individual's attractiveness may have several dimensions, such as wealth, age, looks, personality, and so on. The authors denote the set of elements that determines one's attractiveness by $Z$. Then the quality of an individual's future marriage match and her future husband's income, which are denoted by $\theta_{f}$ and $I_{f}$, respectively, both depend on $Z$. Moreover, it should be noted that one sometimes receives alimony from her previous partner after divorce, which is generally positively correlated with the difference between her previous partner's income and her own income. Thus if an individual divorces, her expected indirect utility function can be expressed as

$$
E\left[v\left(I_{w}+A\left[I_{h}-I_{w}\right], I_{f}[Z]\right)+\theta_{f}(Z)\right]
$$

where $E 0$ is the expectations operator, and $v 0$ is a strictly increasing function of both of its variables. $A O$ denotes the alimony she receives from her previous partner, which increases with $I_{h}-I_{w}$. Finally, if one remains single after divorce, then, clearly, $I_{f}=0$. Meanwhile, in this case, the authors normalize $\theta_{f}$ to be zero.

Then an individual will choose to divorce if and only if

$$
\begin{aligned}
D= & E\left[v\left(I_{w}+A\left[I_{h}-I_{w}\right], I_{f}[Z]\right)+\theta_{f}(Z)\right] \\
& -\left[u\left(I_{w}, I_{h}\right)+\theta(X)\right]>0
\end{aligned}
$$

$D$ is unobservable, but the authors can observe a proxy indicator $I^{*}$ : divorce or remaining married. Thus the empirical analysis will be based on a logit model, in which $I^{*}=1$ (i.e., divorce) if $D>0$ and $I^{*}=0$ (i.e., remaining married) if $D<0$.

Although an individual's divorce decision is influenced by many factors, the authors identify several factors that seem to affect an individual's current or future welfare 
most significantly. Specifically, the authors consider

$$
\begin{aligned}
\boldsymbol{X}= & \{\text { Marital Satisfaction, Religious Beliefs, } \\
& \text { Education }\} \\
\boldsymbol{Z}= & \{\text { Age, Dependent Children, Income }\}
\end{aligned}
$$

Based on this model and the existing theory of divorce, the authors generate the following hypotheses.

\section{A. Marital Satisfaction}

Clearly, the more the marital satisfaction deteriorates, the more likely a couple will choose to divorce.

\section{B. Age}

Age seems to be particularly important for a woman in the marriage market (e.g., Wu, 1994), not only because it is an important determinant of the attractiveness of her looks but also because it greatly affects her fecundity (Siow, 1998). Thus an older woman may face worse perspectives of remarriage, and hence she is less likely to choose to divorce. Further more, as emphasized by Becker (1991), age is often related to the length of marriage. Hence, age is positively related to specific investment in a marriage and may also signify the length of time out of the labor force for women.

\section{Dependent Children}

Because children from current marriage can be a financial burden to a prospective future marriage partner and a source of disputes in future marriage, those with more dependent children may face worse perspectives of remarriage. In this article, dependent children refer to children below age 16 . No matter whether divorced parents remarry or not, parental divorce significantly decreases the "quality" of children from previous marriage in terms of lower educational attainment and various other indicators (e.g., McLanahan and Bumpass, 1988; Hetherington et al., 1998). Because most parents care about their children's welfare, it is hypothesized that the number of dependent children is negatively associated with the probability of divorce. Moreover, there are other attributes of children other than the cost that they impose on the custodial parent. During marriage, children can be considered public good, and parents will suffer a welfare loss if there is a divorce.
Thus the presence of children should reduce the likelihood of divorce.

\section{Wife's Income}

From (2), the authors have

$$
\begin{aligned}
d D / d I_{w}= & E\left[v_{1}^{\prime}\left(I_{w}+A\left[I_{h}-I_{w}\right], I_{f}[Z]\right)\left(1-A^{\prime}\right)\right. \\
& +v_{2}^{\prime}\left(I_{w}+A\left[I_{h}-I_{w}\right], I_{f}[Z]\right)\left[\partial I_{f}(Z)\right] / \partial I_{w} \\
& \left.+\left[\partial \theta_{f}(Z)\right] / \partial I_{w}\right]-u_{1}^{\prime}\left(I_{w}, I_{h}\right) .
\end{aligned}
$$

On one hand, higher income increases one's attractiveness in the remarriage market, which implies $\left[\partial I_{f}(Z)\right] / \partial I_{w}>0$ and $\left[\partial \theta_{f}(Z)\right] / \partial I_{w}>0$. On the other hand, higher income is associated with higher utility from current marriage and less alimony after divorce. Moreover, the higher the income for the wife relative to her husband decreases the likelihood and magnitude of alimony. Thus the impact of a woman's wage rate on her divorce decision is ambiguous.

\section{E. Husband's Income}

On the one hand, higher husband's income is associated with a higher utility from the current marriage. On the other hand, she may receive more alimony after divorce if her husband's income is higher. Formally, from (2), the authors have

$$
\begin{aligned}
d D / d I_{h}= & E\left[v_{1}^{\prime}\left(I_{w}+A\left[I_{h}-I_{w}\right], I_{f}[Z]\right) A^{\prime}\right. \\
& \left.+\left[\left[\partial \theta_{f}(Z)\right] / \partial A\right] A^{\prime}\right]-u_{2}^{\prime}\left(I_{w}, I_{h}\right)
\end{aligned}
$$

Thus the impact of husband's income on the probability of divorce is theoretically ambiguous.

\section{F. Religious Beliefs}

Call and Heaton (1997) suggest that regular church attendance of both husbands and wives reduces the likelihood of divorce (see also, Schumm, 1985, and White, 1990). However, a big difference in attendance between husbands and wives increases the risk of divorce (see Ortega et al., 1988). Moreover, religion often emphasizes the sanctity of marriage and the prohibitions against adultery, both of which serve as barriers to extramarital affairs. Heaton and Pratt (1990) argue that religious denominations may not be as important as affiliation or church attendance in determining the possibility of a marriage's dissolution. 
Thus the net effect of religious belief on divorce probability is ambiguous.

\section{A UNIQUE DATA SET}

Caritas Family Service collected the data set used in this article. A direct consequence of increasing extramarital affairs in Hong Kong is that the divorce rate rose sharply. In response to this increasing social problem, Caritas Family Service set up a Working Group on Extramarital Affairs in December 1993 to provide counseling services to families affected by affairs. Both innocent spouses or spouses involved in affairs could seek counseling services. These counseling services were very valuable because private counseling services were extremely limited and practicing clinical psychologists were not affordable to most families in Hong Kong.

The samples of this data set were randomly chosen from those receiving counseling on extramarital issues provided by Caritas Family Service between 1 January 1994 and 1 April 1995 , when extramarital affairs as a social problem in Hong Kong seemed to be at its worst.

As discussed in the introduction, although nonpecuniary aspects of marriage life are of utmost importance to modern couples, the existing economic literature hasn't examined explicitly the quantitative relationship between marriage satisfaction and divorce. ${ }^{2}$ This negligence is largely due to lack of suitable and reliable data sets. For example, as pointed out by Fair (1978), people are generally reluctant to tell the truth about their private lives to interviewers. Nevertheless, people are more willing to reveal their private lives to their psychologists or counselors particularly at difficult times. Thus an important contribution of this study is that the authors provide a unique data set with accurate and reliable information.

The authors use a logit model to analyze the determinants of the divorce decision. The dependent variable is the dichotomous variable of divorce. The explanatory variables include age, number of dependent children, monthly income, religious belief, educational attainment, and marriage satisfaction before the revelation of the extramarital affairs. The

2. In the sociological literature, Sayer and Bianchi (2000) examine whether a wife's economic independence destabilizes marriage and heightens the risk of divorce. They also discuss marital satisfaction as an indicator of divorce.
TABLE 1

Mean Characteristics of the Sample

\begin{tabular}{lcc}
\hline Variable & $\begin{array}{c}\text { Participating } \\
\text { Spouse }\end{array}$ & $\begin{array}{c}\text { Nonparticipating } \\
\text { Spouse }\end{array}$ \\
\hline Female (\%) & 6.18 & 93.82 \\
& $(421)$ & $(421)$ \\
Age (years) & 39.1 & 37.5 \\
& $(411)$ & $(417)$ \\
Log income & 9.3484 & 8.7735 \\
& $(294)$ & $(209)$ \\
Number of children & 2.14 & 2.14 \\
& $(405)$ & $(405)$ \\
Educational level (\%) & & \\
Primary & 39.0 & 38.8 \\
Secondary & 46.6 & 52.1 \\
Matriculation & 1.9 & 1.5 \\
Postsecondary & 3.8 & 2.5 \\
Degree & 6.5 & 2.5 \\
& $(369)$ & $(399)$ \\
\hline
\end{tabular}

Note: Number of valid observations are reported in parentheses.

authors ran two sets of logit regressions for both participating (i.e., those involved in extramarital affairs) and nonparticipating groups. Because some interviewees refused to disclose their personal data to the interviewers, there are a lot of missing data. Consequently, the valid sample size varies according to the choice of explanatory variables. Mean characteristics of the sample are presented in Table 1.

The total sample size of the data set is 421 couples. As in most Asian societies, the majority of the participants of extramarital affairs are men. In this data set, 395 cases $(93.8 \%)$ of the participants are men and only 26 cases $(6.2 \%)$ are women. This phenomenon is likely to be related to Asian culture, Chinese culture in particular. In traditional Chinese society, married women involved in adultery would be rejected by the community, whereas men's involvement in extramarital affairs were not considered as a big deal. Nowadays, Chinese societies no longer accept polygamy, but the cultural value still influences one's perception toward extramarital affairs. In fact, even in Hong Kong, possibly the most Westernized Chinese society, a double standard of virginity for men and women is still the social norm. Moreover, most of the reported extramarital affairs involved women in mainland China, and the economic integration between the two economies led to sharp increase in total number of Hong Kong male workers to travel extensively 
to mainland China. Hong Kong people are more affluent than those in mainland China. As a result, men from Hong Kong are quite attractive to women in mainland China. This explains why the reported extramarital affairs cases in the data set are largely related to men. On the contrary, both men and women may be involved in extramarital affairs in Western societies, so the gender difference will be relatively small.

The authors divide the sample into two groups, namely, participating spouses and the nonparticipating spouses. Participating spouses refer to those involved in extramarital affairs. The first column of Table 1 shows the characteristics of participating spouses whereas information of nonparticipating spouses is shown in the second column. In principle, both spouses could involve in extramarital affairs, but they were unlikely to seek counseling service. In the sample, there is no couple with both spouses involved in extramarital affairs.

In the data set, each couple had an average of 2.4 children. On average, participating spouses were older and slightly more educated than nonparticipating spouses. Because the first group mainly consists of men, their average log income was higher than that of the other group. In the data set about one-half of women were nonworking, and the reported income was zero. To correct for this sample selection problem, the authors follow the widely used Heckman's (1979) two-stage procedure to estimate the shadow income of nonworking women. Basically, this method involves two equations. One determines an individual's market wage; the other one is a probability equation, which deals with labor force participation.

\section{EMPIRICAL FINDINGS}

This empirical study attempts to examine whether a change in marital satisfaction, due to the discovery of extramarital affairs of one's spousal partner, affects the probability of divorce. ${ }^{3}$ The results show that the perceived change in marital satisfaction is an important determinant in making a divorce decision. Because the dependent variable is a dichotomous variable - a divorce dummy - the

3 Allen and Brinig (1998) hypothesize that the probability of adultery varies over an individual's life cycle. authors use a logit model for the estimation. The regression results for nonparticipating spouses are reported in Table 2.

\section{A. Nonparticipating Spouses}

In Table 2, models 1 to 4 correspond to four logit models with different sets of independent variables. Model 4 can be regarded as a full model, where all relevant independent variables are included in the logit model. The empirical results for model 4 are identical for both participating and nonparticipating spouses. Hence, model 4 is not included in Table 3. The variable marital satisfaction represents the level of marital satisfaction before the discovery of a spouse's extramarital affairs. The variable religion is an individual's devotion to a religion. Dummy variable $C H A N G E$ indicates whether an individual considers his or her spouse's extramarital affair would adversely affect one's marital satisfaction. The variable educated refers to those who received formal education beyond secondary school level.

In the data set, $60.0 \%$ of the respondents considered extramarital affairs would adversely affect one's marital satisfaction. Moreover, only $12.2 \%$ and $6.5 \%$ participating and nonparticipating spouses were classified as educated, respectively.

In model 1 , the authors exclude characteristics of participating spouses. The regression results show that only the dummy variable $C H A N G E$ and the number of children are statistically significant. As expected, the probability of divorce is inversely related to the number of children in a family. On the other hand, the perceived change of marital satisfaction due to extramarital affairs would significantly increase the chance of making a divorce decision. By adding variables relating to participating spouses' characteristics do not materially change the results of the logit models. In models 2 and 3 , the coefficient estimate of marital satisfaction is negative and significant. It means that if one's marital satisfaction before the discovery of extramarital affairs was good, one was less likely to divorce. This result correlates with the authors' intuition.

Even though statistically insignificant, the signs of the estimated coefficients of other independent variables should not be neglected because these may indicate possible relationships between the dependent and the independent variables. The results in Table 2 
TABLE 2

Determinants of Divorce-Spouses Not Participated in Extramarital Affairs

\begin{tabular}{|c|c|c|c|c|}
\hline Variable & Model 1 & Model 2 & Model 3 & Model 4 \\
\hline Age & $\begin{array}{c}0.01807 \\
(0.13053)\end{array}$ & $\begin{array}{c}-0.24578 \\
(0.20876)\end{array}$ & $\begin{array}{c}-0.16516 \\
(0.20844)\end{array}$ & $\begin{array}{c}-.07559 \\
(.29504)\end{array}$ \\
\hline Age (Spouse) & & & $\begin{array}{c}0.30595 \\
(0.22160)\end{array}$ & $\begin{array}{l}0.10618 \\
0.30715\end{array}$ \\
\hline Children & $\begin{array}{r}-0.29920^{*} \\
(0.17566)\end{array}$ & $\begin{array}{c}-0.38316 \\
(0.28903)\end{array}$ & $\begin{array}{c}-0.36345^{* *} \\
(0.18330)\end{array}$ & $\begin{array}{c}-0.59871^{* *} \\
(0.28456)\end{array}$ \\
\hline Educated & $\begin{array}{c}-1.22042 \\
(0.79036)\end{array}$ & $\begin{array}{c}-1.12547 \\
(0.90455)\end{array}$ & & $\begin{array}{c}-1.93433 \\
(1.47203)\end{array}$ \\
\hline Educated (Spouse) & & & & $\begin{array}{c}-0.34450 \\
(0.95633)\end{array}$ \\
\hline CHANGE & $\begin{array}{l}0.68353^{* *} \\
(0.31315)\end{array}$ & $\begin{array}{l}1.44039^{* *} \\
(0.60451)\end{array}$ & $\begin{array}{l}1.22138^{* *} \\
(0.39540)\end{array}$ & $\begin{array}{l}1.25141^{* *} \\
(0.51045)\end{array}$ \\
\hline Female & $\begin{array}{c}0.14249 \\
(0.70338)\end{array}$ & $\begin{array}{c}0.05248 \\
(1.03860)\end{array}$ & $\begin{array}{c}-0.42578 \\
(0.78543)\end{array}$ & $\begin{array}{c}3.21472 \\
(4.78741)\end{array}$ \\
\hline Income & & $\begin{array}{c}-0.20605 \\
(0.33396)\end{array}$ & & $\begin{array}{c}-0.10780 \\
(0.06790)\end{array}$ \\
\hline Income (Spouse) & & & & $\begin{array}{c}0.66094 \\
(0.41960)\end{array}$ \\
\hline Marital satisfaction & & $\begin{array}{c}-0.51938^{*} \\
(0.28300)\end{array}$ & $\begin{array}{c}-0.38661 * * \\
(0.18113)\end{array}$ & $\begin{array}{c}-0.16990 \\
(0.24548)\end{array}$ \\
\hline Religion & $\begin{array}{c}-0.48162 \\
(0.41610)\end{array}$ & $\begin{array}{c}-0.89466 \\
(0.62951)\end{array}$ & $\begin{array}{c}-0.45980 \\
(0.46268)\end{array}$ & $\begin{array}{c}-0.47054 \\
(0.55779)\end{array}$ \\
\hline Religion (Spouse) & & & $\begin{array}{c}0.36942 \\
(0.64144)\end{array}$ & $\begin{array}{c}0.77374 \\
(0.77231)\end{array}$ \\
\hline Constant & $\begin{array}{c}-0.02202 \\
(1.77007)\end{array}$ & $\begin{array}{c}5.51943 \\
(4.19233)\end{array}$ & $\begin{array}{c}0.64217 \\
(2.00781)\end{array}$ & $\begin{array}{c}-12.24521 \\
(10.26344)\end{array}$ \\
\hline Chi-squared & 228.8 & 193.7 & 209.9 & 166.6 \\
\hline$N$ & 225 & 199 & 219 & 152 \\
\hline
\end{tabular}

Note: SEs reported in parentheses. ${ }^{* *}$ Significant at 0.05 level. ${ }^{*}$ Significant at 0.1 level.

suggest that divorce rate decreases with age and educational level. The probability of divorce is lower for those who indicate a religion. When one gets older, the chance for a second marriage after divorce will decrease. If individuals are rational, the authors should expect the divorce rate decreases with age. Other things being equal, more educated persons are more likely to make a rational choice. The empirical results confirmed the authors' conjecture and are in line with the basic economic assumption that economic agents are rational.

The empirical results largely confirm with the authors' first four hypotheses discussed in section II. Yet the impact of income on the probability of divorce is somewhat ambiguous. Moreover, most nonparticipating spouses were selected to be economically inactive. Although the authors used the two-stage Heckit to impute the income for nonworking women, the standard errors of the relevant coefficient estimates are rather large. Hence, it does not give us a clear direction of the impact of income on divorce rate. Furthermore, a popular newspaper in Hong Kong reported that a majority of women were unable to collect their alimonies after divorce. Unlike their counterparts in Western countries, these divorced women seldom go to court for assistance in collecting their alimonies.

In Chinese societies like Hong Kong, people are exposed to a variety of religions and beliefs, notably Confucian and Buddhism. In fact, the basic concepts of Confucianism are transmitted through studying Chinese literature in local schools. Other than those who go to a handful of international schools in Hong Kong, students are required to take Chinese literature as one of three compulsory subjects (the other two subjects are mathematics and English) at primary and secondary school levels. As a result, even though a respondent indicates a Catholic or other Christian religion, he or she is unlikely to be unaffected by 
TABLE 3

Determinants of Divorce-Spouses Participated in Extramarital Affairs

\begin{tabular}{lccc}
\hline Variable & Model 1 & Model 2 & Model 3 \\
\hline Age & 0.09645 & 0.11310 & 0.30595 \\
& $(0.14358)$ & $(0.18643)$ & $(0.22160)$ \\
Age (Spouse) & & -0.16516 \\
Children & -0.26208 & $-0.59856^{* *}$ & $-0.30844)$ \\
& $(0.17418)$ & $(0.26968)$ & $(0.18330)$ \\
Educated & -0.10416 & $-1.15801^{* *}$ & \\
Educated (Spouse) & $(0.48731)$ & $(0.71220)$ & \\
CHANGE & & & $1.22138^{* *}$ \\
& $0.73699^{* *}$ & $1.30373^{* * *}$ & $(0.39540)$ \\
Female & $(0.32041)$ & $(0.50217)$ & 0.42578 \\
& -0.10004 & -4.92936 & $(0.78543)$ \\
Income & $(0.70866)$ & $(11.01844)$ & \\
Income (Spouse) & & 0.53516 & \\
Marital satisfaction & & $(0.35674)$ & $-0.38661^{* *}$ \\
Religion & & -0.23023 & $(0.18113)$ \\
Religion (Spouse) & & $(0.23379)$ & 0.26942 \\
Constant & -0.02320 & 0.17192 & $(0.64144)$ \\
Chi-squared & $(0.44926)$ & $(0.52510)$ & -0.45980 \\
$N$ & & & $(0.46268)$ \\
& & -0.91922 & $(1.73397)$ \\
& -1.09180 & $(11.66424)$ & 209.881 \\
& $(1.54719)$ & 151.078 & 219 \\
\hline
\end{tabular}

Note: SEs reported in parentheses. ${ }^{* *}$ Significant at 0.05 level. ${ }^{*}$ Significant at 0.1 level.

Confucian and Buddhism. Thus it is not surprising that the standard errors of the relevant coefficient estimates are large.

\section{B. Participating Spouses}

Having studied the determinants of divorce decision for nonparticipating spouses, the authors now turn to the determinants of divorce for participating spouses. Because these people were personally involved in extramarital affairs, they should have a higher dissatisfaction with the current marriage. However, the authors have no a priori expectation whether they have a different set of determinants of divorce than those of nonparticipating spouses. Table 3 presents logit regression results for participating spouses.

All three logit results presented in Table 3 suggest that the dummy variable $C H A N G E$ is an important predictor of divorce. In other words, those couples who perceived their marital satisfaction was adversely affected by extramarital affairs were more likely to end up with a divorce. As expected, those with higher number of children were less willing to divorce. The Chinese culture looks unfavorably on single-parent families. People may even discriminate against children brought up in single-parent families. Hence, it is natural to expect that those with more children in the family are less likely to make a divorce decision. Similar to results in Table 2 , the higher marital satisfaction before the discovery of extramarital affairs, the less likely a couple ended up with a divorce.

\section{EXTRAMARITAL AFFAIRS, DIVORCE, AND POLICY IMPLICATIONS}

Most civil societies greatly value family as a vital unit that provides an intimate environment in which personal care, mutual support, and emotional security are normally available to its members. The extent to which a family can meet these expectations depends on a healthy and stable marital relationship. In the past few decades, the core family relationship in 
the world has been radically altered. The worldwide rapid increase in divorce rate and in the unwed birth rate in some countries have been the most dramatic event resulting from this significant change of household structure (e.g., Becker, 1991).

Among various threats that can jeopardize the spousal relationship, the most important one is infidelity. The discovery of a spouse's involvement in an extramarital affair is possibly one of the most stressful life events. The wronged spouse may perceive a loss of the other's love, a loss of the exclusivity of marital relationship, a loss of the image of a happy family, a loss of self-worth, a loss of income, or any combination of these. Very often, he or she may experience an identity crisis and is forced to adopt a new status in the family. Thus, extramarital affairs usually result in deterioration in the quality of marriage and sometimes lead to the dissolution of a family.

Divorce usually affects the living standards of women and children. For example, using the PSID data, Duncan and Hoffman (1985) find that divorced women in the United States suffer an average fall of about $30 \%$ in their incomes the year after their marriages broke up, and this figure does not change much over the next few postdivorce years. In fact, divorced mothers account for a large and growing proportion of the poor in most developed countries. Meanwhile, children with divorced biological parents usually have significantly lower educational attainment no matter whether the divorced parents remarry or not (e.g., McLanahan and Bumpass, 1988).

As in many other aspects of family law, public authorities have traditionally restricted the autonomy of spouses when applying for a divorce. Unilateral divorce and divorce with mutual consent are, in fact, a relatively recent phenomenon. The restrictions placed on divorce by the government are often explained in the following two ways (e.g., Cabrillo, 1999). First, divorce involves not only the interests of the partners but also those of the children whom the government has a duty to protect. Second, family stability is a public good from which the whole society benefits. However, when serious tensions exist between the partners, artificial maintenance of a marriage may not really benefit any member of the family and the society.

This article suggests a better and more effective public policy than restricting divorce. It is advisable for the government to take measures to reduce the likelihood of the negative shocks (e.g., infidelity) that affect marital satisfaction. For example, in mainland China, those involve in extramarital affairs are liable to prosecution. Moreover, the government should subsidize the agencies that provide psychological services to the families with serious marital problems. Also, the government may increase the alimony for divorces that are caused by extramarital affairs and increase the penalty for those who refuse to pay the alimony on time.

\section{CONCLUSION AND FURTHER DISCUSSION}

This article provides the first empirical study to examine the impact of the change of marital satisfaction due to a spouse's involvement in extramarital affairs. The authors employed a unique data set collected by a social welfare agency in Hong Kong. The authors first set up a simple model, in which marital satisfaction enters a couple's utility function. The authors assume individuals are rational and forwardlooking in their responses to their spouses' involvement in extramarital affairs. An individual will choose to divorce if and only if his or her expected utility from his or her future alternatives after divorce is greater than his or her utility from remaining married.

Based on the authors' model and the existing theory, the authors empirically test several hypotheses. The regression analysis indicates that $60 \%$ of the respondents believed extramarital affairs would adversely affect the marital satisfaction and they were more likely to divorce. Moreover, couples with more children in a family were less willing to make a divorce decision. This is in line with Chinese cultural value and children brought up in single-parent families are sometimes discriminated by their peers. On the other hand, good marital quality before the discovery of extramarital affairs would lower the chance of getting a divorce. Finally, although statistically insignificant, the empirical results show that divorce rate decreases with age, religion, and educational level. Finally, this article generates several policy implications.

The authors presented stylized facts relating to divorce decisions of those couples with a spouse involved in extramarital affairs. Yet many questions remain unanswered. Most problems with the empirical analysis rest with the 
limitations of the data set, which only includes troubled marriages. The authors would encourage other researchers to conduct dedicated surveys to collect suitable data for analysis. These surveys should include troubled marriages and normal marriages in the sample. Information on the following should be included: birth order, coresidence of a parent, length of marriage, duration of the adulterous relationship, intensity of religious observance and who receives custody of children. With more comprehensive data sets, researchers could have a better understanding of the determinants of divorce.

\section{REFERENCES}

Aghajanian, A. "Some Notes on Divorce in Iran." Journal of Marriage and the Family, 48, 1986, 749-55.

Allen, D. W. "No-Fault Divorce in Canada: Its Cause and Effect." Journal of Economic Behavior and Organization, 37(2), 1998, 129-49

Allen, D. W., and M. Brinig. "Sex, Property Rights, and Divorce." European Journal of Law and Economics, 5(3), 1998, 211-33.

Becker, G. S. "A Theory of Marriage: Part I." Journal of Political Economy, 81(4), 1973, 813-46.

. A Treatise on the Family, Cambridge, MA: Harvard University Press, 1991.

Becker, G. S., E. M. Landes, and R. T. Michael. "An Economic Analysis of Marital Instability." Journal of Political Economy, 85(6), 1977, 1141-87.

Berggren, N. "Rhetoric or Reality? An Economic Analysis of the Effects of Religion in Sweden." Journal SocioEconomics, 26(6), 1997, 571-96.

Boheim, R., and J. Ermisch. "Partnership Dissolution in the UK-The Role of Economic Circumstances." Oxford Bulletin of Economics and Statistics, 63(2), 2001, 197-208.

Cabrillo, F. The Economics of the Family and Family Policy, Northampton, MA: Edward Elgar, 1999.

Call, V. R. A., and T. B. Heaton. "Religious Influence on Marital Stability." Journal for the Scientific Study of Religion, 36(3), 1997, 382-92.

Census and Statistics Department. Demographic Trends in Hong Kong 1981-2001. Hong Kong: Government Printer, 2002.

Cheung, S. N. S. "The Enforcement of Property Rights in Children, and the Marriage Contract." Economic Journal, 82, 1972, 641-57.

Clarke S. C. Advance Report of Final Divorce Statistics, 1989 and 1990. Monthly Vital Statistics, volume 43, no. 9 supplement. Hyattsville, MD: National Center for Health Statistics, 1995a.

Advance Report of Final Marriage Statistics, 1989 and 1990. Monthly Vital Statistics, volume 43, no. 12 supplement. Hyattsville, MD: National Center for Health Statistics, $1995 \mathrm{~b}$

Duncan, G. J., and S. D. Hoffman. "A Reconsideration of the Economic Consequences of Marital Dissolution." Demography, 22(4), 1985, 485-97.
Ellwood, D., and M. J. Bane. "The Impact of AFDC on Family Structure and Living Arrangements." In Research in Labor Economics, vol. 7, edited by Ronald Ehrenberg. Greenwich, C: JAI Press, 1985, 137-207.

Fair, R. C. "A Theory of Extramarital Affairs." Journal of Political Economy, 86(2), 1978, 45-61.

Fogel, R. W. "Catching up with the Economy." American Economic Review, 89(1), 1999, 1-21.

Heaton, T. B., and E. L. Pratt. "The Effects of Religious Homogamy on Marital Satisfaction and Stability." Journal of Family Issues, 11(2), 1990, 191-207.

Heckman, J. J. "Sample Selection Bias as a Specification Error." Econometrica, 47, 1979, 153-61.

Hetherington, E. M., M. Bridges, and G. M. Insabella. "What Matters? What Does Not? Five Perspectives on the Association between Marital Transitions and Children's Adjustment." American Psychologist, 53, 1998, 167-84.

Hiedemann, B., O. Suhomlinova, and A. M. O'Rand "Economic Independence, Economic Status, and Empty Next in Midlife Marital Disruption.” Journal of Marriage and the Family, 60, 1998, 219-31.

Hoffman, S. D., and G. J. Duncan. "The Effect of Incomes, Wages and AFDC Benefits on Marital Disruption." Journal of Human Resources, 30(1), $1995,19-41$.

Lee, M.-K., and S.-H. Lu. "The Marriage Institution in Decline?" In Indicators of Social Development: Hong Kong 1995, edited by S. Lau, M. Lee, O. Wan, and S. Wong. Hong Kong: Chinese University Press, 1997.

Liao, C., and T. B. Heaton. "Divorce Trends and Differentials in China." Journal of Comparative Family Studies, 23(3), 1992, 413-29.

Lillard, L. A., and L. J. Waite. "Determinants of Divorce." Social Security Bulletin, 53(2), 1990, 29-31.

Lundberg, S., and R. Pollak. "Separate Spheres Bargaining and the Marriage Market." Journal of Political Economy, 101(6), 1993, 988-1010.

McLanahan, S., and L. Bumpass. "Intergenerational Consequences of Family Dissolution." American Journal of Sociology, 94(1), 1988, 130-52.

Moffitt, R. "The Effect of the US Welfare System on Marital Status." Journal of Public Economics, 41(1), 1988, 101-24.

Morgan, S. P., and R. R. Rindfuss. "Marital Disruption: Structural and Temporal Dimensions." American Journal of Sociology, 90, 1988, 1055-77.

Nock, S., and M. Brinig. "Weak Men and Disorderly Women: Divorce and the Division of Labor," In The Law and Economics of Marriage and Divorce, edited by Antony W. Dnes and Robert Rowthorn. Cambridge: Cambridge University Press, 2002.

Ortega, S. T., H. P. Whitt, and J. A. William Jr. "Religious Homogamy and Marital Happiness." Journal of Family Issues, 9(2), 1988, 224-39.

Posner, R. Sex and Reason. Cambridge, MA: Harvard University Press, 1992.

Sayer, L. C., and S. M. Bianchi. "Women's Economic Independence and the Probability of Divorce: A Review and Reexamination." Journal of Family Issues, 21(7), 2000, 906-1043.

Schumm, W. R. "Beyond Relationship Characteristics of Strong Families: Constructing a Model of Family Strengths." Family Perspective, 19, 1985, 1-19. 
Scott, J., M. Braun, and D. Alwin. "The Family Way." In International Social Attitudes: the 10th BSA Report, edited by Roger Jowell, Lindsay Brook, and Lizanne Dowds. Aldershot: Gower Publishing, 1993.

Siow, A. "Differential Fecundity, Markets, and Gender Roles." Journal of Political Economy, 106(2), 1998, 334-54.

South, S. J. "Economic Conditions and the Divorce Rate: A Time-Series Analysis of the Post-War United States." Journal of Marriage and the Family, 47, 1985, 31-41.

Sutton, P. D., and M. L. Munson. Births, Marriages, Divorces, and Deaths: Provisional Data for September 2003. National Vital Statistics Reports, volume 52, no. 16, Hyattsville, MD: National Center for Health Statistics, 2004.

Trent, K., and S. J. South. "Structural Determinants of the Divorce Rate: A Cross-Societal Analysis." Journal of Marriage and the Family, 51, 1989, 391-404.
Walters, M. S., and R. W. Ressler. "An Economic Model of Cohabitation and Divorce." Journal of Economic Behavior and Organization, 40, 1999, 195-206.

Weiss, Y., and R. J. Willis. "Children as Collective Goods and Divorce Settlements." Journal of Labor Economics, 3(3), 1985, 268-92.

"Match Quality, New Information, and Marital Dissolution." Journal of Labor Economics, 15(1), 1997, S293-S329.

White, L. K. "Determinants of Divorce: A Review of Research in the Eighties." Journal of Marriage and the Family, 52, 1990, 904-12.

Wu, Z. "Remarriage in Canada: A Social Exchange Perspective." Journal of Divorce \& Remarriage, 21(3/4), 1994, 191-224.

$\mathrm{Xu}, \mathrm{X}$., and M. K. Whyte. "Love Matches and Arranged Marriages: A Chinese Replication." Journal of Marriage and the Family, 52(3), 1990, 709-22. 